\title{
ACTIVITY SCHEDULE AND AFFECTIVE CONTROL OF COMPONENT BASED PROJECT
}

\author{
P. K. Suri ${ }^{1}$, Karambir ${ }^{2}$ \\ ${ }^{I}$ Dean (Academic and Research \& Development) and Chairman,(CSE/DCSA) Deptt, HCTM, Kaithal, Haryana, India \\ ${ }^{2}$ Assistant Professor, CSE,UIET, Kurukshetra University, Kurukshetra, Harayan, India
}

\begin{abstract}
Abstract The overall performance of any organizations depends on the way the project is managed and scheduled. The successful implementation of one or two big or complex project does not indicate that this organization will perform In the same way in future. Component based implementation of software development projects in the automotive industry have to face the rapid strategies for the use of the latest technologies that would provide the success of this type of projects, namely the frequency of change requirements during the life cycle. The cost and time for software testing was analyzed and to avoid delays in the project and more to cope with disturbances caused by changing requirements in the each phase of the project life cycle. Using of Component Based Software Engineering $(C B S E)$ in software company, the implementation of any software project has become easy but the integration of available component or their use is the not only skill of project manager but the delivery of project in time is a required. The project manager ensure the success of their project as a competitive advantage and establish such a system which will work with limited resources and available time. The project management tools and techniques i.e. Critical Path Methods(CPM) or Program Evaluation and Review Techniques (PERT) are used in reality as the most valuable and are planned to be used in the component based software testing system. This research result point out that there is a huge difference between planned and unplanned testing project. It also shows that the time of testing can be reduced with increase of cost of failure as a result the company may decide the benefit from that project. Analysis of the results allows to determine dependencies between level of company's maturity level in project management, used project management tools and techniques, and values gained by the company from project management time to time with measured risk factor.
\end{abstract}

Key Words: K Component Base Software Engineering(CBSE), CPM, PERT, Project life cycle, planned or unplanned project

\section{INTRODUCTION}

Components based software engineering is the branch of Software Engineering that became popular due to rapid change in the requirement of user and absorption of new technology. By using the principle of this engineering, the new project can be designed and developed within specified time with defined quality for user requirement. As per the survey, it was found that the testing of this project take much time and cost than the developing it. First of all, when a new component is developed then the test case are designed as per the environment of developer and manual of test case is supplied with this to developer. When it is delivered to the software developer, then the developer will use this component in new environment and integrate with his own system. It is tested again and new test cases will be added to list of previous test cases. These customized test cases will be documented in a report and with the release of software these report is also embedded with this for easiness to user. Further the project is used by the client that may have slightly different requirement than already designed. Then maintaince or developer team will customize this project as per the requirement of user. Then this project is to be tested again. Retest of complete project may take more time if the team test it at first stage. To avoid this hectic and delay, the tester will first identify the component or group of components that is to tested with utmost care. The planning of testing is required for estimating the time of testing, cost and moreover the benefit of any organizations. Although a vast amount of research has been done in project management competences, there is no standard set of project management competences used[1]. One of the main cause affecting the project planning is the actual economy and lack of availability of the all the resources. The lack of resources during the project progress both at the actual component developer level and mostly at the software developer level that is using these components level leads to delays, penalties and loss of opportunities which are reflected in the favor of project and organization, as a whole it was considered[2] that the unsteady economic conditions make the liquidity risk the least understood and the most dangerous financial risk because it reduces the control we have over existing risks and forces companies to assume other risks which normally they would not like to hold.

\section{LITERATURE REVIEW}

The pre-estimation of job completion time has led to development of many procedures time to time. A method was proposed an approximation to determine job completion time[3] after identifying in networks activities graph among various paths. After study of Four major newspapers over a 
20 year period, it was observed that the job requirements changed over time [4] for programmers, IS managers, and system analysts. The organizations[5][15] place more importance on interpersonal/management skills, business functional knowledge, and technology management knowledge as opposed to technical knowledge. In a subsequent study, [6] conducted a content analysis of IT job advertisements posted and analyzed the trends in skill set requirements for IT professionals. Consistent with the results reported by [4], they found that there was still a strong demand for IT professionals with technical skills. A two-stage study[7] was focused on (1) human skills of communication and delegation, (2) skills of planning and organizing, and (3) technical skills. .The Standish Group International [9] reported a drastic decrease in the success of project that $44 \%$ of all IT projects was delivered late, over budget, and/or without meeting the requirements and more than $24 \%$ being either canceled prior to completion or delivered. The skills of IT project managers[10] were concentrated on enhancing these skills for the successful execution of IT projects. The management of project leader reflects the production capacity as well as the development potential of the team as well as the organization. The management of software system components are programs written for integrating these components, projects and other operational activities like testing result analysis and its documentation. The CPM and PERT tools[6] for project planning attracted the attention of both the practitioners and researchers and to find the job completion time in PERT networks graph is important for planning and time estimation purposes.

\section{MOTIVATIONAL TECHNIQUE}

In this competition, the price of software for user is coming down. In order to win the faith of user, the organizations accept a large number of risks, which significantly affect the project implementation. The biding prices lead to a continuing reduction of the project budgets and profit margins of companies. The use of new technologies and the creation of innovative products involves changes of requirements during project development. These components are prioritized and grouped according to certain characteristics, defining a sequence of activities. Like in all software development projects, the necessity to reach the project milestones is essential for the project success.

\subsection{Critical Path Method (CPM)}

$\mathrm{P}$ The critical path method (CPM) is an algorithm for scheduling a set of project activities. It is an important tool for effective project management for any project. Any project with inter dependent activities can apply this method for mathematical analysis of delivery of that project. The essential technique for using CPM [6] [7] is to construct a model of the project that includes the following (1) A list of all activities required to complete the project, the time to complete, and dependencies graph between the activities. Using these values, CPM calculates the longest path of planned activities to the end of the project, and the earliest and latest that each activity can start and finish without making the project longer. This process determines which activities are critical i.e. longest path. In project management, a critical path is the sequence of project network activities which gives the longest duration. This determines the shortest time possible to complete the project. Any delay of an activity on the critical path directly impacts the planned project completion date. A project can have several, parallel, near critical paths.

\subsection{Program Evaluation and Review Techniques (PERT)}

PERT is a management and evaluation tool for defining activity and integrating these activity for completing a project's objectives on time. A process that can be applied to any sort of project which requires planning, controlled, and integrated work patterns. PERT is applicable for the events to manage where multiple tasks are going simultaneously to reduce the redundancy. The project scheduling depend upon project's size, complexity, duration, personnel, and owner requirements. One of its most powerful concepts is the management of probabilities. This makes use of simple statistical mathematics for calculating a probability distribution for the completion dates of the project milestones. Project time is the based on the total of (1) Management information time for real time problem . (2) probability time of probability of completion. The estimation of time for the completion of each activity is important in the network analysis; this can be done using (1) Minimum Time or Most optimistic time (2) Maximum Time or Most pessimistic time. The expected completion duration is assumed to be normally distributed between most optimistic and most pessimistic time and the

$$
\text { Voriance }=\left(\frac{\text { Most Pessimistic Time }- \text { Most Optmistic Time }}{6}\right)^{2}----1
$$

\section{SOFTWARE TESTING TIME SCHEDULE MANAGEMENT}

\subsection{Assumptions}

The management of project is series of multi activities. Here as an example the testing of Component based system has been taken for research purpose. The testing is represented by the network graph of activities. In network graph in given below fig 1 , the node is represented as the end of task and branch or arrow between nodes is the activities.

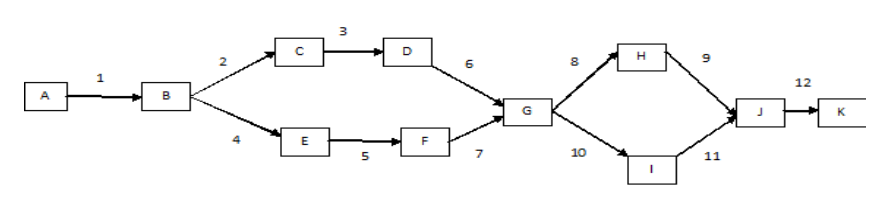

Fig-1: Activity Network Graph of Activities of Component Testing. 


\subsection{Model Implementation}

$\mathrm{P}$ The distribution of activities of testing is given in table no. 1 below. The time to complete is taken from two types of events i.e. best when the full resource whole time persons are devoted to this activity and the worse case when unskilled persons are working on this activity. Every time the activity cannot be worse or best, so the normal distributed time is taken for this event at any time of project activity.

\begin{tabular}{|c|c|c|c|}
\hline Sr No & Activity & $\begin{array}{l}\text { Best } \\
\text { Time }\end{array}$ & $\begin{array}{l}\text { Worst } \\
\text { Time }\end{array}$ \\
\hline 1 & $\begin{array}{l}\text { Identify the } \\
\text { Component to be } \\
\text { Tested }\end{array}$ & 4 & 7 \\
\hline 2 & $\begin{array}{l}\text { Formalize } \\
\text { Specification }\end{array}$ & 7 & 10 \\
\hline 3 & $\begin{array}{l}\text { Component Test } \\
\text { Case Design }\end{array}$ & 5 & 7 \\
\hline 4 & $\begin{array}{l}\text { Previous Repository } \\
\text { of Test Case }\end{array}$ & 2 & 4 \\
\hline 5 & $\begin{array}{l}\text { Customize Test } \\
\text { Cases }\end{array}$ & 12 & 15 \\
\hline 6 & Select Tool & 2 & 4 \\
\hline 7 & $\begin{array}{l}\text { Writing of Script } \\
\text { Test Case }\end{array}$ & 6 & 11 \\
\hline 8 & $\begin{array}{l}\text { Configure/Install } \\
\text { Component }\end{array}$ & 3 & 5 \\
\hline 9 & $\begin{array}{l}\text { Run Testing } \\
\text { Software System }\end{array}$ & 3 & 7 \\
\hline 10 & Feasible Report & 4 & 6 \\
\hline 11 & $\begin{array}{l}\text { Documentation } \\
\text { Report }\end{array}$ & 5 & 9 \\
\hline 12 & $\begin{array}{l}\text { Release Component } \\
\text { Base Software }\end{array}$ & 4 & 6 \\
\hline
\end{tabular}

Table -1: Component Testing Activity with Allotted Time

on The average time of activities is taken as the normally distributed and it is calculated and precedence table is prepared for the simulation for calculating the time to complete the testing project. Pseudorandom number is generated in Mat lab 7 by equation -1

\section{Random No $=$ First no $+($ Second - First $) *$ rand $(1,200)---2$ \\ Normal Distributed $=\operatorname{mean}(\operatorname{mean}($ Random No $)+\operatorname{std}($ Random No $) * \operatorname{rand}(1,200))---3$}

From Fig 1 is observed that the $2^{\text {nd }}$ and $4^{\text {th }}$ activity can not start until the $1^{\text {st }}$ activities is finished. $3^{\text {rd }}$ activity start after finishing the $2^{\text {nd }}$ activity. $8^{\text {th }}$ and $10^{\text {th }}$ activity start the end of $6^{\text {th }}$ and $7^{\text {th }}$ activities.

To avoid the confusion and smooth working of consequence activities, the early start time of each activity is to be determined. The chain of sequence of activity $2^{\text {nd }}, 3^{\text {rd }} 6^{\text {th }}$ or $4^{\text {th }}, 5^{\text {th }}$ an $7^{\text {th }}$ terminate their service at different time. The largest of time to complete the chain sequence of any path of these two will be considered the start time of $8^{\text {th }}$ or $10^{\text {th }}$ activity.

\begin{tabular}{|c|c|c|c|}
\hline Sr No & Activity & $\begin{array}{c}\text { Node } \\
\text { Presentation }\end{array}$ & $\begin{array}{c}\text { Normal } \\
\text { Distributed } \\
\text { Time } \\
\end{array}$ \\
\hline 1 & $\begin{array}{l}\text { Identify the } \\
\text { Component to be } \\
\text { Tested }\end{array}$ & A-B & 5.9208 \\
\hline 2 & $\begin{array}{l}\text { Formalize } \\
\text { Specification }\end{array}$ & $\mathrm{B}-\mathrm{C}$ & 8.9376 \\
\hline 3 & $\begin{array}{l}\text { Component Test } \\
\text { Case Design }\end{array}$ & C-D & 6.2471 \\
\hline 4 & $\begin{array}{l}\text { Previous Repository } \\
\text { of Test Case }\end{array}$ & B-E & 3.2485 \\
\hline 5 & $\begin{array}{l}\text { Customize Test } \\
\text { Cases }\end{array}$ & E-F & 13.9029 \\
\hline 6 & Select Tool & D-G & 3.3104 \\
\hline 7 & $\begin{array}{l}\text { Writing of Script } \\
\text { Test Case }\end{array}$ & F-G & 9.0735 \\
\hline 8 & $\begin{array}{l}\text { Configure/Install } \\
\text { Component }\end{array}$ & G-H & 4.2557 \\
\hline 9 & $\begin{array}{l}\text { Run Testing } \\
\text { Software System }\end{array}$ & H-J & 5.6356 \\
\hline 10 & Feasible Report & G-I & 5.3027 \\
\hline 11 & $\begin{array}{l}\text { Documentation } \\
\text { Report }\end{array}$ & I-J & 7.6369 \\
\hline 12 & $\begin{array}{l}\text { Release Component } \\
\text { Base Software }\end{array}$ & $\mathrm{J}-\mathrm{K}$ & 5.3294 \\
\hline
\end{tabular}

Table -2: C Component Testing Activity, Nodes and Normal Distributed Time

\section{RESULT AND ANALYSIS}

The critical path found from the Fig no 1 is A-B-E-F-G-I-J$\mathrm{K}$. The other path that can be followed to complete the project are here as table no III the variance column in table no III is sum of the variance for the corresponding path. This variance shows the variance in time to complete the project.

\begin{tabular}{|c|c|c|}
\hline Sr No & Path & Variance \\
\hline 1 & A-B-E-F-G-I-J-K(critical) & 1.972 \\
\hline 2 & A-B-C-D-G-H-J-K & 1.2778 \\
\hline 3 & A-B-C-D-G-I-J-K & 1.3889 \\
\hline 4 & A-B-E-F-G-H-J-K & 2.222 \\
\hline
\end{tabular}

Table -3: Path Followed and Variance in Project Path 
If the manager of testing can determine that if the critical path is followed then the number of days to complete this project is 50.4 days and variance is 1.97 .

$Z$ value $=\frac{\text { Proposed Time }- \text { Estimated Time }}{\text { standard deviation }}--4$

\begin{tabular}{|l|l|l|l|l|l|}
\hline $\begin{array}{l}\text { Sr } \\
\text { No }\end{array}$ & EST & EFT & LST & LFT & Variance \\
\hline 1 & 0 & 5.92 & 0 & 5.92 & 0.25 \\
\hline 2 & 5.92 & 14.86 & 13.65 & 22.59 & 0.25 \\
\hline 3 & 14.86 & 21.11 & 22.59 & 28.84 & 0.111111 \\
\hline 4 & 5.92 & 9.17 & 5.92 & 9.17 & 0.111111 \\
\hline 5 & 9.17 & 23.07 & 9.17 & 23.07 & 0.25 \\
\hline 6 & 21.11 & 24.42 & 28.84 & 32.15 & 0.111111 \\
\hline 7 & 23.07 & 32.15 & 23.07 & 32.15 & 0.694444 \\
\hline 8 & 32.15 & 36.4 & 35.19 & 39.45 & 0.111111 \\
\hline 9 & 36.4 & 42.04 & 39.45 & 45.09 & 0.444444 \\
\hline 10 & 32.15 & 37.45 & 32.15 & 37.45 & 0.111111 \\
\hline 11 & 37.45 & 45.09 & 37.45 & 45.09 & 0.444444 \\
\hline 12 & 45.09 & 50.41 & 45.09 & 50.41 & 0.111111 \\
\hline
\end{tabular}

Table -4: Schedule of Activity in forward and Backward Way

As to create highly innovative or highly beneficial products, the product should be adaptable to the change of requirement as precondition. It is very important to ensure the maximum effective value of shortening activities' duration for every step of shortening duration process. On one hand, for reduce the steps of shortening, it is necessary to shorten duration as much as possible in every step. On the other hand, useless shortening should be avoided in shortening process, which not only couldn't shorten the period of a project but also increase cost of shortening. The maximum effective shortening is determined by the margin between the different lengths of paths contain critical path and non-critical path. It is a technique for estimating and planning a large project. The $\mathrm{z}$-value was calculated from equation 4 and Fig 2 was drawn from the value of $Z$ with the help of Table 4.

The manager found from network graph that if more effort is put on the activity customization of test case then the time of completion can be reduced. Then some more person were put on this activity and it was completed in 7 days, the Fig 3 Shows the great difference for the two cases here. after experience of manager, with time the repository is accumulated with all possible of test case.

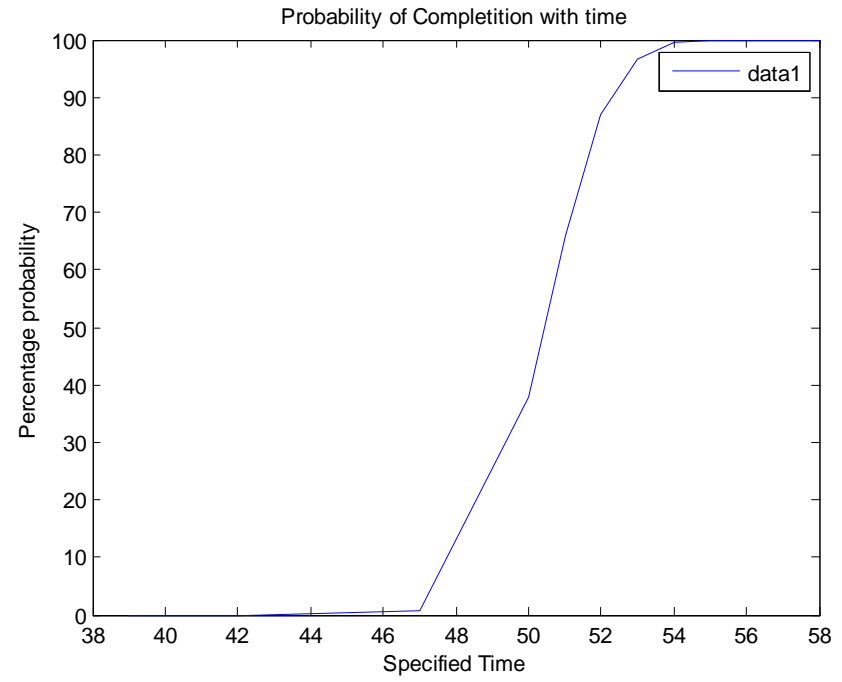

Fig -2: Probability to Complete project w.r.t Time

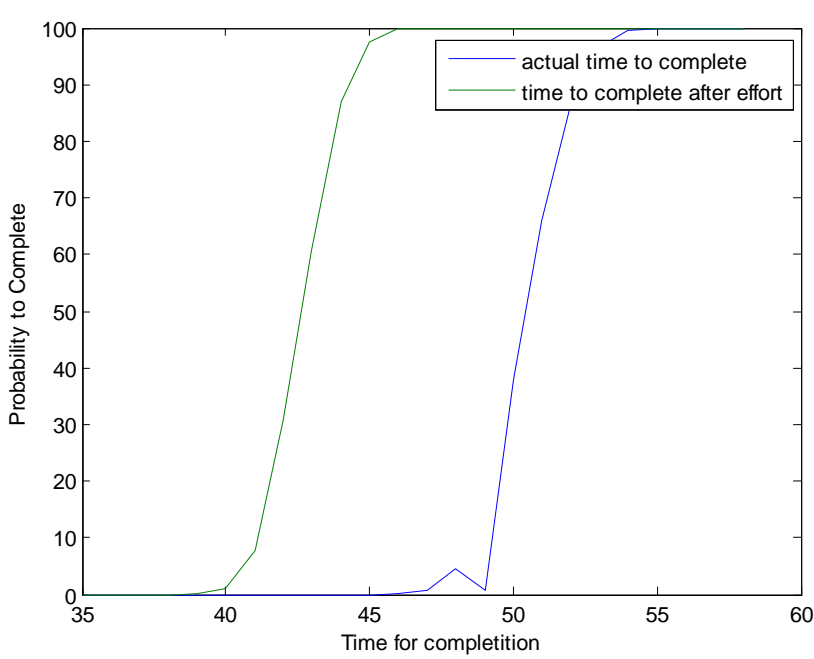

Fig -3: Comparision of Probability to Complete Project With Time if Particular Activity is Identified for more Effort

And then the customization of test case can be improved and time to finish the activity will be reduced. The target of the manager is simple to achieve and client will get its project within the stipulated time and as result of this the software developer can more benefit out of it.

\section{CONCLUSIONS}

To sustain Project oriented organizations in a market, it need to set integrated project and portfolio success image. To prove this, project schedule with in limited resources should be accurate.. Keeping Risk factor in mind, the simulation for finding the schedule on the basis of network graph was applied. The application of such models without considering resource constraints may lead to wrong and dangerous decisions. The requirement and financial condition cannot be fixed at the first stage of project. The CPM and PERT method with some flexibility was simulated here and time was taken as normally distributed between best and worse time. A particular importance was given to the software testing of project and the level of project 
prioritization was changed in order to obtain the maximum profit, the maximum earnings and to minimize the expenses, the costs and the duration. It was analyzed the variability of the probability to achieve the target date for components during the change of projects level of priority and manager identified the section of activity what can be more variation of the probability to achieve the target duration and expenses is highly. Analyzing the variance and rescheduling of project can give project in time and more benefit to software developer.

\section{REFERENCES}

[1] Nijhuis, S. A., "Learning for project management in a higher education curriculum", Project Management Institute Research and Education Conference, Limerick, Ireland, 2012

[2] N Borge D. , The book of risk, John Wiley \& Sons., Inc, ISBN 0-471-32378-0 , 2001

[3] Mahhotra Kishan, "A Study of Approximating theMoments of the job completion Time in PERT Networks", Elecrtical Engineering and Computer Science technical Reports, Paper -113,1991

[4] P.A. Todd, J.D. McKeen, R.B. Gallupe,'The evolution of IS job skills: a content analysis of IS job advertisements from 1970 to 1990”, MIS Quarterly 9 (1), 1995, pp. 1-27, 1995

[5] D.M.S. Lee, E.M. Trauth, D. Farwell, "Critical skills and knowledge requirements of IS professionals: a joint academic/industry investigation", MIS Quarterly 9 (3), 1995, pp. 313-340, 1995

[6] M.J. Gallivan, D.P. Truex, L. Kvasny," Changing patterns in IT skill sets 1988-2003: a content analysis of classified advertising", SIGMIS Database 5 (3), 2004, pp. 64-87, 2004

[7] S. El-Sabaa, "The skills and career path of an effective project manager", International Journal of Project Management 9 (1), pp. 1-7, 2001

[8] N.P. Napier, M. Keil, F.B. Tan, 'IT project managers' construction of successful project management practice: a repertory grid investigation", Information Systems Journal 9 (3), pp. 255-282, 2009

[9] The Standish Group International, CHAOS Summary, http://www1.standishgroup.com/ newsroom/ chaos_2009.php , 2009

[10] J. Wateridge, "Training for IS/IT project managers: a way forward", International Journal of Project Management 5 (5), pp. 283-288, 1997

[11]R. Schmidt, K. Lyytinen, M. Keil, P. Cule, "Identifying software project risks: an international Delphi study", Journal of Management Information Systems 7 (4), pp. 5-36, 2001

[12] J.M. Verner, W.M. Evanco, "In-house software development: what project management practices lead to success?", IEEE Software 2 (1), pp. 86-93, 2005

[13] J.J. Jiang, G. Klein, S. Margulis, "Important behavioral skills for IS project managers: the judgments of experienced IS professionals", Project Management Journal 9 (1), pp. 39-43, 1998
[14] G. Skulmoski, F. Hartman, "Information systems project manager soft competencies: a project-phase investigation", Project Management Journal 1 (1), pp. $61-80,2010$ 